\title{
Effect of biofertilizers with various levels of inorganic nutrients on growth and yield of black cumin (Nigella sativa L.) var. Azad Kalonji
}

\author{
Jamir, A.R. ${ }^{1}{ }^{\circledR}$, Chattopadhyay, N. $^{1}$, Momin M.C. ${ }^{2}$
}

\begin{abstract}
The objective of the study is to reduce the amount of inorganic fertilizers by using biofertilizers with the aim of sustainable agriculture. The field experiment was conducted at the HRS, Mondouri, BCKV, West Bengal, India during rabi season of 2019-20. The experiment consisted of 14 treatments replicated thrice, comprising of three levels inorganic fertilizers (50, 75 and 100\%) of recommended NPK and three biofertilizers viz. Azospirillum lipoferum (N fixer), Bacillus megaterium (potash mobilizer) and Fraturia aurantia (K mobilizer) as soil application. The results indicated that the maximum plant height $(86.06 \mathrm{~cm})$ at $100 \mathrm{DAS}$, number of primary $(10.66)$ and secondary branches $(17.33)$, number of capsules plant $^{-1}(25.33)$, number of seeds capsule ${ }^{-1}(97.66)$, test weight $(3.54 \mathrm{~g})$ and projected yield $\left(538.50 \mathrm{~kg} \mathrm{ha}^{-1}\right) \mathrm{were}^{2}$ recorded in $100 \%$ RDF + Azospirillum + PSB + KS. The yield was at par with $75 \%$ RDF + Azospirillum + PSB + KS $\left(536.74 \mathrm{~kg} \mathrm{ha}^{-1}\right)$. Considering the economics, maximum net return (Rs. 1,08,083.74 $\mathrm{ha}^{-1}$ ) and $\mathrm{B}$ : C ratio (4.14: 1) was obtained from 75\% RDF + Azospirillum + PSB + KS. These results suggested that combination of Azospirillum + PSB + KS with $75 \%$ RDF was best for optimum production of black cumin without loss in yield and reduction of $25 \%$ of inorganic fertilizers through application of biofertilizers and environmental pollution to some extent.
\end{abstract}

Key words: Azospirillum, Bacillus, Biofertilizers, Black cumin, Economics, Fraturia, Inorganic

\section{Introduction}

Black cumin (Nigella sativa L.) is an annual flowering species of the family Ranunculaceae. It is an important seed spices crop native to Mediterranean region and widely grown across Middle East, Europe and Asia. The crop is cultivated in different parts of the world (Aggarwal et al., 2008; Al-Sman et al., 2017). The leading producers are India, Sri Lanka, Bangladesh, Pakistan, Afghanistan, Egypt, Iraq, Iran, Turkey, Syria and Ethiopia. Among the countries, India, Syria, Ethiopia and Turkey are the major exporter (Sultana et al., 2018). It is widely grown for its flavorful seeds and leaves, used as culinary spices in Indian and Middle Eastern cuisines. They are used for flavouring of foods, especially cheese and bakery products and in preparation of black cumin pastry. The seeds are also associated with various medicinal properties and are widely used in

\section{Author's Address}

${ }^{1}$ Department of Plantation, Spices, Medicinal and Aromatic Crops, Bidhan Chandra Krishi Viswavidyalaya, Mohanpur741252, Nadia, West Bengal, India.

${ }^{2}$ Department of Post-Harvest Technology, Bidhan Chandra Krishi Viswavidyalaya, Mohanpur-741252, Nadia, West Bengal, India.

E-mail.: alemjamirhorti@gmail.com
Ayurveda, Unani, Siddha and other ethnomedicine systems all over the world (Padmaa, 2010). The extracts of seeds have numerous medicinal properties like antihelmintic, antibacterial, antiviral, antipyretic, galactagogue, carminative and antidiabetic effects (Salem, 2005; Darakhshan et $a l ., 2015)$. In recent years, there is increased use of biofertilizers as a supplement to nutrient supply in agricultural system due to increasing cost of chemical fertilizers and global concern for environmental pollution. Feeding is one of the key aspects affecting the quantity and quality of medicinal plants (Arun, 2002). The most critical constraint limiting crop yield in developing countries globally and especially among the poor farmers, is soil infertility (Khosro and Yousef, 2012). So, maintaining soil fertility and supplying optimum level of nutrients from all feasible sources in an integrated way is necessary to sustain the desired productivity of crop (Chundawat, 2001). We can increase the efficiency of nutrient inputs with proper nutrition of plants, while preserving environment, biodiversity and reducing erosion. Besides, avoiding the unnecessary utilization and consumption of nutrients, we will be able to reduce 
costs of production to minimum which could be taken into consideration as a step to sustainable agriculture (Safaei et al., 2014). Application of chemical fertilizers and pesticides increases soil acidity and poses the risk of polluting ground water and the atmosphere. It also impairs the roots of plants decreasing the ability for proper absorption of water and nutrients thereby making them susceptible to undesirable diseases (Chun-Li et al., 2014). In this view, biofertilizers has been identified as an alternative form to chemical fertilizers to improve soil fertility and crop production. Biofertilizers are cultures of special bacteria and fungi and unlike inorganic and organic nutrients they do not supply any nutrient directly to the plants. Biofertilizers comprises of symbiotic nitrogen fixers Rhizobium spp., asymbiotic nitrogen fixers (Azospirillum, Azotobacter, etc.), blue green algae, Azolla, phosphate solubilizing bacteria and potash mobilizing mycorrhizae (Goel et al., 1999). The application of biofertilizers is known to promote plant growth through the supply of plant nutrients and may support to sustain environmental health and productivity of the soil (O' Connell, 1992). Karlidag et al., 2007 demonstrated that biofertilizer could minimize the chemical fertilizer requirement and reduce its adverse impact on the environment. Fayez et al. 1985 reported that Azotobacter chroococcum and Azospirillum lipoferum not only have the potential to fix nitrogen but also release phytohormones similar to gibberellic acid and indole acetic acid, which could enhance nutrients absorption, plant growth and photosynthesis. Phosphate solubilizing bacteria promotes plant growth through the synthesis of antibiotics, phytohormones and few enzymes such as ACC (1-aminocyclopropane-1-carboxylate) deaminase that adjusts the level of plant hormones and makes phosphorous available to the plants by solubilization and mineralization of inorganic and organic phosphate (Rodriguez and Fraga, 1999). Potassium solubilizing bacteria solubilise minerals directly such as orthoclase, illite and micas which bears potassium by dissolving rock potassium by secreting organic acids or release potassium into solution by chelating silicon ions (Barker et al., 1998). Plant nutrition is one of the main elements that influence the growth and yield of crop plants and biofertilizers offers an efficient and ecologically sustainable way of minimizing external inorganic inputs and maintaining natural land resources. In general, only $10 \%$ to $40 \%$ of the total applied fertilizers are taken up by plants and remaining $60 \%$ to $90 \%$ is lost. Therefore, biofertilizers can be an effective component in integrated nutrient management systems for sustaining agricultural productivity and a healthy environment (Adesemoye and Kloepper, 2009). So, considering the importance of biofertilizers on optimization of nutrients, the present experiment was designed to find out the effect of biofertilizers with different grades of inorganic fertilizer on growth and yield of black cumin.

\section{Materials and Methods}

Experimental site: The field experiment was carried out during rabi season (November to March) of 2019-2020 at Horticultural Research Station, Mondouri of Bidhan Chandra Krishi Viswavidyalaya, Nadia, West Bengal, India. The area is in new alluvial zone which is situated between $22^{\circ} \mathrm{N}$ latitude and $88^{\circ} \mathrm{E}$ longitude with an altitude of $13 \mathrm{~m}$ above sea level. The soil of experimental field had $6.06 \mathrm{pH}, 0.72 \%$ organic carbon, $237.5 \mathrm{~kg} \mathrm{ha}^{-1}$ available nitrogen, $14.3 \mathrm{~kg} \mathrm{ha}^{-}$ ${ }^{1}$ available phosphorus and $226.4 \mathrm{~kg} \mathrm{ha}^{-1}$ available potassium.

Experimental design and details: The field experiment was laid out in randomized complete block design (RCBD), replicated thrice comprising of 14 treatments. Nitrogen fixing bacteria (Azospirillum lipoferum), phosphate solubilizing bacteria (Bacillus megaterium) and potassium solubilizer (Fraturia aurantia) with a concentration of $2 \times 10^{7} \mathrm{cfu} \mathrm{g}^{-1}$ were applied with three levels of recommended dose of NPK i.e., 100\%, 75\% and $50 \%$. The treatment combinations were $\mathrm{T}_{1}-100 \%$ $\mathrm{RDF}+$ Azospirillum, $\mathrm{T}_{2^{-}} 100 \% \mathrm{RDF}+\mathrm{PSB}, \mathrm{T}_{3^{-}}$ $100 \% \mathrm{RDF}+\mathrm{KS}, \mathrm{T}_{4}-100 \% \mathrm{RDF}+$ Azospirillum $+\mathrm{PSB}+\mathrm{KS}, \mathrm{T}_{5^{-}} 75 \% \mathrm{RDF}+$ Azospirillum, $\mathrm{T}_{6^{-}} 75$ $\% \mathrm{RDF}+\mathrm{PSB}, \mathrm{T}_{7^{-}} 75 \% \mathrm{RDF}+\mathrm{KS}, \mathrm{T}_{8^{-}} 75 \% \mathrm{RDF}$ + Azospirillum $+\mathrm{PSB}+\mathrm{KS}, \mathrm{T}_{9}-50 \% \mathrm{RDF}+$ Azospirillum, $\mathrm{T}_{10^{-}} 50 \% \mathrm{RDF}+\mathrm{PSB}, \mathrm{T}_{11^{-}} 50 \%$ $\mathrm{RDF}+\mathrm{KS}, \mathrm{T}_{12}-50 \% \mathrm{RDF}+$ Azospirillum $+\mathrm{PSB}+$ $\mathrm{KS}, \mathrm{T}_{13}-$ Azospirillum $+\mathrm{PSB}+\mathrm{KS}$ and $\mathrm{T}_{14}$ (control) $-100 \% \operatorname{RDF}\left(\mathrm{N}_{40} \mathrm{P}_{40} \mathrm{~K}_{45}\right)$.

Nutrient application and sowing: Biofertilizers were applied as sole or in combination along with each level of inorganic fertilizers. Biofertilizers 
were mixed thoroughly with farm yard manure (FYM) and applied directly to the soil @ $2.5 \mathrm{~kg}$ ha ${ }^{1}$ each during field preparation. The total amount of inorganic fertilizer was applied at three split doses. $1 / 3^{\text {rd }}$ of $\mathrm{N}$ along with full dose of $\mathrm{P}$ and $\mathrm{K}$ were applied 7 days before sowing and rest $2 / 3^{\text {rd }}$ of $\mathrm{N}$ was applied in two splits during later stage at 40 and 60 days after sowing. Urea, single super phosphate and muriate of potash were used as inorganic source of $\mathrm{N}, \mathrm{P}_{2} \mathrm{O}_{5}$ and $\mathrm{K}_{2} \mathrm{O}$.

Prior to sowing, the seeds of black cumin variety Azad kalonji were soaked in water overnight before sowing to promote early germination and treated with Trichoderma viride@ $2 \mathrm{~g} \mathrm{~kg}^{-1}$ seed. The seeds were sown in a plot size of $2.1 \times 1.5 \mathrm{~m}$ in a row of $30 \mathrm{~cm}$ spacing and the seedlings were thinned out at 30 days after sowing at a distance of $15 \mathrm{~cm}$.

Statistical analysis: During the experimentation period, five random plants from each treatment and replications were selected for observations. The experimental data recorded were subjected to statistical analysis by employing RCBD at 5\% level of significance for determination of critical difference (CD). The data were analyzed using a window based computer package OPSTAT (Sheoran, 2004).

\section{Results and Discussion}

Plant height and number of branches: The results obtained from the present experiment are presented in the Table 1. The plant height (86.06 $\mathrm{cm})$ at 100 days after sowing (DAS), average number of primary branches (10.66) and secondary branches (17.33) of plant during harvest were significantly higher under $\mathrm{T}_{4}$, where $100 \% \mathrm{RDF}+$ Azospirillum + PSB + KS were used. The treatment comprising of Azospirillum + PSB + KSB without chemical fertilizers $\mathrm{T}_{13}$ recorded the least number of primary (5.80) and secondary (5.21) branches and lowest plant height $(50.14 \mathrm{~cm})$. The results are in agreement with study carried out in onion, where maximum plant height was recorded under the application of $100 \%$ NPK and biofertilizers (Das et al., 2020). Valadabadi and Farahani, 2013 reported similar finding in black cumin, where maximum plant height $(84 \mathrm{~cm})$ was recorded under the treatment of Azotobacter and animal manure. Ali and Hassan, 2014 reported that the maximum plant height $(54.72 \mathrm{~cm})$ and average number of branches
(11.47) were recorded under the application NFB (mixture of Azotobacter chroococcum and Azospirillum brasilense) and PSB (mixture of Bacillus megatherium var. phosphaticum and Bacillus polymyxa) along with cattle manure in black cumin. Sen et al., 2019 also recorded highest number of branches in black cumin under 100\% RDF chemical fertilizers, FYM and biofertilizer treatment. In celery, height of the plants has increased with the application of biofertilizers which enhanced the content of nitrogen and photosynthesis rate (Migahed et al., 2004). Biofertilizers produces phytohormones that provide favourable effect on active root rhizosphere by causing faster multiplication and elongation of cells that helped in proliferation of roots and improves nutrient uptake resulting in better vegetative growth including plant height, number of primary and secondary branches. Increase in growth attributes can be correlated to the positive impact of biofertilizers on uptake of nutrients by plants (Gad, 2001). Increased plant growth could also be associated to suitable combination of inorganic nutrients and biofertilizers which provide immediate availability of nutrients at initial stage through inorganic fertilizers and at steady and constant rate as long term availability through the process of biofertilizers resulting in higher plant height and number of branches. Combined applications of Azospirillum, PSB and KS have significant effect than their sole application along with inorganic fertilizers. The application of Azospirillum helped in increasing nitrogen availability through atmospheric nitrogen fixing which reflected on better production of growth and yield attributes. PSB effects the production of organic acids, vitamins, amino acids, IAA and GA which helped in obtaining better growth as well as yield and yield attributes of the plants. KS solubilise potassium bearing minerals and convert to soluble form from insoluble $\mathrm{K}$ and make them available to the plants. Silicate minerals can be dissolved by KSB and potassium is released through the production of inorganic and organic acids (Prasad et al., 2018).

Yield and yield attributes: Plants supplied with $100 \% \mathrm{RDF}+$ Azospirillum $+\mathrm{PSB}+\mathrm{KS}\left(\mathrm{T}_{4}\right)$ was recorded with maximum number of capsules plant ${ }^{-1}$ (25.33), number of seeds capsule ${ }^{-1}$ (97.66), test weight $(3.54 \mathrm{~g})$ and projected yield $\left(538.50 \mathrm{~kg} \mathrm{ha}^{-1}\right)$ 
Jamir et al.

Table 1: Effect of biofertilizers and inorganic fertilizers on growth, yield and yield attributes of black cumin var. Azad Kalonji

\begin{tabular}{|c|c|c|c|c|c|c|c|c|c|}
\hline \multirow[b]{2}{*}{ Treatment } & \multicolumn{3}{|c|}{ Plant height } & \multicolumn{2}{|c|}{ Number of branches } & \multirow{2}{*}{$\begin{array}{l}\text { No. of } \\
\text { Capsule } \\
\text { plant }^{-1}\end{array}$} & \multirow{2}{*}{$\begin{array}{l}\text { No. of } \\
\text { seeds } \\
\text { capsule }^{-1}\end{array}$} & \multirow{2}{*}{$\begin{array}{l}1000 \\
\text { seed } \\
\text { wt. (g) }\end{array}$} & \multirow{2}{*}{$\begin{array}{l}\text { Projected } \\
\text { yield }(\mathrm{kg} \\
\left.\mathrm{ha}^{-1}\right)\end{array}$} \\
\hline & $\begin{array}{l}60 \\
\text { DAS }\end{array}$ & $\begin{array}{l}80 \\
\text { DAS }\end{array}$ & $\begin{array}{l}\text { 100 } \\
\text { DAS }\end{array}$ & Primary & Secondary & & & & \\
\hline$T_{1}$ & 29.90 & 57.16 & 80.83 & 9.33 & 15.33 & 23.33 & 96.66 & 3.32 & 494.78 \\
\hline$T_{2}$ & 27.83 & 53.66 & 78.83 & 8.66 & 14.66 & 22.66 & 96.50 & 3.25 & 491.75 \\
\hline $\mathbf{T}_{3}$ & 24.73 & 45.16 & 78.40 & 8.00 & 14.33 & 21.45 & 96.33 & 3.19 & 490.84 \\
\hline $\mathbf{T}_{4}$ & 31.33 & 58.43 & 86.06 & 10.66 & 17.33 & 25.33 & 97.66 & 3.54 & 538.50 \\
\hline $\mathbf{T}_{5}$ & 28.02 & 57.00 & 82.33 & 8.66 & 13.33 & 20.33 & 94.36 & 2.98 & 489.79 \\
\hline$T_{6}$ & 27.76 & 51.66 & 72.26 & 7.68 & 12.66 & 19.50 & 94.00 & 2.90 & 483.96 \\
\hline$\overline{T_{7}}$ & 23.13 & 44.50 & 69.13 & 7.33 & 11.33 & 19.33 & 93.50 & 2.85 & 477.01 \\
\hline$T_{8}$ & 30.83 & 58.16 & 84.50 & 9.66 & 16.86 & 24.66 & 97.33 & 3.47 & 536.74 \\
\hline$T_{9}$ & 27.90 & 54.23 & 73.66 & 6.68 & 8.66 & 16.66 & 89.33 & 2.79 & 392.33 \\
\hline$T_{10}$ & 25.76 & 46.73 & 60.36 & 6.45 & 6.83 & 15.90 & 87.50 & 2.75 & 388.81 \\
\hline$T_{11}$ & 22.50 & 43.24 & 58.16 & 6.20 & 6.33 & 15.50 & 87.10 & 2.70 & 383.97 \\
\hline$T_{12}$ & 30.73 & 57.13 & 64.86 & 7.10 & 9.33 & 18.20 & 86.86 & 2.72 & 399.64 \\
\hline$T_{13}$ & 21.26 & 40.16 & 50.14 & 5.80 & 5.21 & 13.33 & 84.33 & 2.56 & 298.91 \\
\hline$T_{14}$ & 27.24 & 57.00 & 78.60 & 9.00 & 14.00 & 21.83 & 94.22 & 3.06 & 499.94 \\
\hline $\operatorname{SEm}( \pm)$ & 0.400 & 0.755 & 1.091 & 0.125 & 0.205 & 0.310 & 1.310 & 0.045 & 6.853 \\
\hline CD at $5 \%$ & 1.169 & 2.208 & 3.188 & 0.364 & 0.598 & 0.907 & 3.830 & 0.131 & 20.032 \\
\hline
\end{tabular}

Note: $\mathrm{T}_{1}-100 \% \mathrm{RDF}+$ Azospirillum, $\mathrm{T}_{2}-100 \% \mathrm{RDF}+\mathrm{PSB}, \mathrm{T}_{3}-100 \% \mathrm{RDF}+\mathrm{KS}, \mathrm{T}_{4^{-}}-100 \% \mathrm{RDF}+$ Azospirillum $+\mathrm{PSB}+\mathrm{KS}, \mathrm{T}_{5^{-}}-75 \% \mathrm{RDF}$ + Azospirillum, $\mathrm{T}_{6}-75 \% \mathrm{RDF}+\mathrm{PSB}, \mathrm{T}_{7^{-}} 75 \% \mathrm{RDF}+\mathrm{KS}, \mathrm{T}_{8^{-}} 75 \% \mathrm{RDF}+$ Azospirillum $+\mathrm{PSB}+\mathrm{KS}, \mathrm{T}_{9}-50 \% \mathrm{RDF}+$ Azospirillum, $\mathrm{T}_{10^{-}} 50 \%$ $\mathrm{RDF}+\mathrm{PSB}, \mathrm{T}_{11}-50 \% \mathrm{RDF}+\mathrm{KS}, \mathrm{T}_{12}-50 \% \mathrm{RDF}+$ Azospirillum $+\mathrm{PSB}+\mathrm{KS}, \mathrm{T}_{13}-$ Azospirillum $+\mathrm{PSB}+\mathrm{K}$ and $\mathrm{T}_{14}$ (Control) $-100 \% \mathrm{RDF}$ $\left(\mathrm{N}_{40} \mathrm{P}_{40} \mathrm{~K}_{45}\right)$.

Table 2: Gross return, Net return and B: $C$ ratio of black cumin as influenced by biofertilizers and various levels of inorganic fertilizers

\begin{tabular}{|c|c|c|c|c|}
\hline Treatments & $\begin{array}{l}\text { Total cost of } \\
\text { cultivation (Rs.) }\end{array}$ & $\begin{array}{ll}\text { Gross } & \text { return } \\
\text { (Rs.) } & \\
\end{array}$ & Net return (Rs.) & B:C ratio \\
\hline $\mathbf{T}_{\mathbf{1}} 100 \% \mathrm{RDF}+$ Azospirillum & $26,952.00$ & $1,23,695.00$ & $96,743.00$ & 3.58 \\
\hline $\mathbf{T}_{2} 100 \% \mathrm{RDF}+\mathrm{PSB}$ & $26,952.00$ & $1,22,937.50$ & $95,985.50$ & 3.56 \\
\hline $\mathbf{T}_{\mathbf{3}} 100 \% \mathrm{RDF}+\mathrm{KS}$ & $26,952.00$ & $1,22,710.00$ & $95,759.00$ & 3.55 \\
\hline $\mathbf{T}_{4} 100 \% \mathrm{RDF}+$ Azospirillum $+\mathrm{PSB}+\mathrm{KS}$ & $27,232.00$ & $1,34,625.00$ & $1,07,393.00$ & 3.94 \\
\hline $\mathbf{T}_{5} 75 \% \mathrm{RDF}+$ Azospirillum & $25,821.26$ & $1,22,447.50$ & $96,626.24$ & 3.74 \\
\hline $\mathbf{T}_{6} 75 \% \mathrm{RDF}+\mathrm{PSB}$ & $25,821.26$ & $1,20,990.00$ & $95,168.74$ & 3.68 \\
\hline $\mathbf{T}_{7} 75 \% \mathrm{RDF}+\mathrm{KS}$ & $25,821.26$ & $1,19,252.50$ & $93,431.24$ & 3.61 \\
\hline $\mathbf{T}_{\mathbf{8}} 75 \% \mathrm{RDF}+$ Azospirillum $+\mathrm{PSB}+\mathrm{KS}$ & $26,101.26$ & $1,34,185.00$ & $1,08,083.74$ & 4.14 \\
\hline $\mathbf{T}_{\mathbf{9}} 50 \%$ RDF + Azospirillum & $24,690.88$ & $98,082.50$ & $73,391.62$ & 2.97 \\
\hline $\mathbf{T}_{10} 50 \% \mathrm{RDF}+\mathrm{PSB}$ & $24,690.88$ & $97,202.50$ & $72,511.62$ & 2.93 \\
\hline $\mathbf{T}_{11} 50 \% \mathrm{RDF}+\mathrm{KS}$ & $24,690.88$ & $95,992.50$ & $71,301.62$ & 2.88 \\
\hline $\mathbf{T}_{\mathbf{1 2}} 50 \% \mathrm{RDF}+$ Azospirillum $+\mathrm{PSB}+\mathrm{KS}$ & $24,970.88$ & $99,910.00$ & $74,939.12$ & 3.00 \\
\hline $\mathbf{T}_{\mathbf{1 3}}$ Azospirillum $+\mathrm{PSB}+\mathrm{K}$ & $22,710.00$ & $74,727.50$ & $52,017.50$ & 2.29 \\
\hline $\mathbf{T}_{14} 100 \% \operatorname{RDF}\left(\mathrm{N}_{40} \mathrm{P}_{40} \mathrm{~K}_{45}\right)$ & $26,812.00$ & $1,24,985.00$ & $98,173.00$ & 3.66 \\
\hline
\end{tabular}

which was at par under $\mathrm{T}_{8}(75 \% \mathrm{RDF}+$ et al., 2011 recorded that the maximum yield was Azospirillum + PSB + KS) $(24.66,97.33,3.47 \mathrm{~g}$ obtained under full RD of N + biofertilizer during and $536.74 \mathrm{~kg} \mathrm{ha}^{-1}$ respectively), indicating that there is a chance of reducing of $25 \%$ recommended RDF through biofertilizers without any reduction in first year and $2 / 3$ of full $\mathrm{RD}$ of $\mathrm{N}+$ biofertilizer in second year in dill. Das et al., 2020 also reported that the application of biofertilizers can save $25 \%$ yield (Table 1). These results are in agreement with inorganic fertilization in garlic. The least number of the findings of Sahu et al., 2014 in coriander. Hellal capsules plant ${ }^{-1}$ (13.33), number of seeds capsule ${ }^{-1}$ 
(84.33), test weight $(2.56 \mathrm{~g})$ and projected yield $\left(298.91 \mathrm{~kg} \mathrm{ha}^{-1}\right)$ were recorded under $\mathrm{T}_{13}$ (Azospirillum + PSB + KS). Kusuma et al., 2019 recorded that the maximum number of yield attributes like umbels plant ${ }^{-1}$, umbellets umbel $^{-1}$, seeds umbellet ${ }^{-1}$ and projected yield was obtained with the application of $75 \% \mathrm{RDN}+\mathrm{RDPK}+\mathrm{FYM}$ + Azospirillum + PSB in fennel. Abdel-Azieza et al., 2013 reported that the productivity and quality of black cumin was improved when Azotobacter was applied along with half dose of nitrogen fertilizers. The combined application inorganic fertilizers and biofertilizers were significantly higher in overall improvement in yield and yield attributes. This might be due to the influence of biofertilizers by increasing photosynthetic efficiency and translocation of photosynthates towards flowers and seeds development. And also the activities of microorganisms to mobilize the soil bound minerals to the plants in soluble form during its growing period resulting in better nourishment of crop, which led to production of higher yield.

Economics: The economics of the experiment under different treatment was calculated with respect to gross return, net return and benefit cost ratio (B:C ratio). The data is presented in Table 2 . The maximum gross return (Rs. 1,34,625.00 ha-1) was recorded under $\mathrm{T}_{4}(100 \% \mathrm{RDF}+$ Azospirillum $+\mathrm{PSB}+\mathrm{KS})$ which was at par with $\mathrm{T}_{8}(75 \% \mathrm{RDF}$ + Azospirillum + PSB + KS) (Rs. 1,34,185.00 ha $\left.{ }^{-1}\right)$. But the net return (Rs. 1,08,083.74 ha ${ }^{-1}$ ) and B: C ratio (4.14) was recorded higher under $\mathrm{T}_{8}$. This was due to $25 \%$ reduction of inorganic fertilizers. Roy and Hore, 2010 also reported higher plant growth,

\section{References}

Abdel-Azieza, S.M., Ewedab, W.E., Girgisb, M.G.Z. and Ghanya, B.F.A. 2013. Improving the productivity and quality of black cumin (Nigella sativa) by using Azotobacter as N2 biofertilizer. Annals of Agricultural Science. 59: 95-108.

Adesemoye, A.O. and Kloepper, J.W. 2009. Plant-microbes interactions in enhanced fertilizer use efficiency. Applied Microbiology Biotechnology.85: 1-12.

Aggarwal, B., Kunnumakkara, A., Harikumar, K., Tharakan, S., Sung, B. and Anand, P. 2008. Potential of spice-derived phytochemicals for cancer prevention. Planta Medica, 74: 1560-1569. yield and B: C ratio with NPK $(75 \%)+$ Azospirillium + VAM in turmeric, which indicate that $25 \%$ of inorganic fertilizer can be reduced. The lowest gross return (Rs. 74,727.50 ha $\mathrm{h}^{-1}$ ), net return (Rs. 52,017.50 $\mathrm{ha}^{-1}$ ) and B: C ratio (2.29) was observed under $\mathrm{T}_{13}$ (Azospirillum $+\mathrm{PSB}+\mathrm{KS}$ ). Singh et al., 2012 reported that the combined application of $75 \%$ RDF + Rhizobium + PSB was suitable in terms yield and net return, resulting in saving $25 \%$ RDF in kasuri methi. It can be concluded that the application of biofertilizers along with inorganic fertilizers can significantly increase the profit in black cumin production.

\section{Conclusion}

The application of Azospirillum, PSB and KS can significantly improve the productivity by reducing the amount of inorganic fertilizer requirement. The improvement of growth and yield attributes of black cumin may be associated to growth promoting substances that acted on plant development process. On the basis of results, it may be concluded that combined application of $75 \%$ $\mathrm{RDF}+$ Azospirillum + PSB + KS were found to be effective for higher yield, net return and $\mathrm{B}$ : $\mathrm{C}$ ratio and resulted in reduction of $25 \%$ RDF due to constant and steady availability and supply of mineralized nutrients to the plants. Thus, the application of $75 \% \mathrm{RDF}+$ Azospirillum + PSB + KS can be recommended for production of black cumin in new alluvial zone of West Bengal to get higher economic yield and return thereby reducing environmental pollution to some extent.

Ali, E. and Hassan, F. 2014. Bio-production of Nigella sativa L. seeds and oil in Taif area. International Journal of Current Microbiology and Applied Science. 3: 315-328.

Al-Sman, K.M., Abo-El-Yousr, A.M.K. and Eraky Amal. and El-Zawahry Aida. 2017. Isolation, identification and biomanagement of root rot of black cumin (Nigella sativa) using selected bacterial antagonists. International Journal of Phytopathology, 6: 47-56.

Arun, K.S. 2002. A handbook of organic farming. Agrobios Publisher, India.

Barker, W.W., Welch, S.A., Chu, S. and Banfield, J.F. 1998. Experimental observations of the effect of bacteria on alumino silicate weathering. American Mineralogist, 83: 1551-63. 


\section{Jamir et al.}

Chundawat, B.S. 2001. Integrated nutrient management in tropical and subtropical Fruits. Indian Journal of Horticulture, 58: 59-69.

Chun-Li, W., Shiuan-Yuh, C. and Chiu-Chung, Y. 2014. Present situation and futureperspective of bio-fertilizer for environmentally friendly agriculture. Annual Reports. 1-5.

Darakhshan, S., Tahvilian, R., Colagar, A.H., Babolsar, I. 2015. Nigella sativa: A plant with multiple therapeutic implications. International Journal of Pharmacognosy, 2: 190-214.

Das, S., Rahman, F.H., Mukherjee, S. and Nag, K. 2020. Response of biofertilizers and primary nutrients on growth and yield of garlic (Allium sativum L.) in new alluvial soil of West Bengal. Current Journal of Applied Science and Technology, 39: 1-7.

Fayez, M., Emam, N.F. and Makboul, H.E. 1985. The possible use of nitrogen fixing Azospirilum as biofertilizer for wheat plants. Egyptian Journal of Microbiology, 20: 199-206.

Gad, W.M. 2001. Physiological studies on Foeniculum vulgare Mill. and Anethum graveolens L. M.Sc Thesis. Faculty of Agriculture. Kafr El-Sheikh. Tanta University of Egypt.

Goel, A.K., Laura, R.D.S., Pathak, G., Anuradha, G. and Goel, A. 1999. Use of bio-fertilizers: potential, constraints and future strategies review. International Journal of Tropical Agriculture, 17: 1-18.

Hellal, F.A., Mahfouz, S.A. and Hassan, F.A.S. 2011. Partial substitution of mineral nitrogen fertilizer by bio-fertilizer on (Anethum graveolens L.) plant. Agriculture and Biology Journal of North America. 2: 652-660.

Karlidag, H., Esitken, A., Turan, M. and Sahin, F. 2007. Effects of root inoculation of plant growth promoting rhizobacteria (PGPR) on yield, growth and nutrient element contents of leaves of apple. Scientia Horticulturae, 114: 16-20.

Khosro, M. and Yousef, S. 2012. Bacterial bio-fertilizers for sustainable crop production: A review APRN. Journal of Agricultural and Biological Science, 7: 237-308.

Kusuma, M.V., Venkatesha, J., Ganghadarappa, P.M., Hiremath, J.S., Mastiholi, A.B. and Manjunatha, G. 2019. Effect of integrated nutrient management on growth and yield of fennel (Foeniculum vulgare Mill.). International Journal of Current Microbiology and Applied Sciences. 8: 2319-7706.

Migahed, H.A., Ahmed, A.E. and Abdel Ghany, B.F. 2004. Effect of different bacterial strains as biofertilizers agents on growth, production and oil of Apium graveolens under calcareous soil. Arab Universities Journal of Agricultural Science, 12: 511-525.

O'Connell, P.F. 1992: Sustainable agriculture- a valid alternative. Outlook Agriculture, 21: 5-12.
Padmaa, P.M. 2010. Nigella sativa Linn.- A comprehensive review. Indian Journal of natural products and resource, 1: 409-429.

Prasad, N.V., Uma Jyothi, K., Sudhavani, V., Sujatha, R.V. and Pratyusha Bhagavati, P. 2018. Studies on effect of biofertilizers in combination with inorganic nutrients on yield paramters and quality parameters of sprouting broccoli (Brassica oleracea var. italica L.). International Journal of Chemical Studies, 6: 1168-1170.

Rodríguez, H. and Fraga, R. 1999. Phosphate solubilizing bacteria and their role in plant growth promotion. Biotechnology Advances, 17: 319-339.

Roy, S.S. and Hore, J.K. 2010. Influence of biofertilizers along with inorganic nutrition on growth, yield and quality of turmeric grown as intercropping in arecanut plantation. Environment and Ecology, 28: 2587-90.

Safaei, Z., Azizi, M., Davarynejad, G. and Aroiee, H. 2014. The effect of foliar application of humic acid and nanofertilizer (Pharmks $\left.{ }^{\circledR}\right)$ on yield and yield components of black cumin (Nigella sativa L.). Journal of Medicinal Plants and Byproducts, 2: 133-140.

Sahu, R.L., Sahu, H. and Kumar, S. 2014. Effect of application of inorganic fertilizers and biofertilizers on growth components and yield traits of coriander (Coriandrum sativum L.). Progressive Horticulture, 46: 102-106.

Salem, M.L. 2005. Immunomodulatory and therapeutic properties of the Nigella sativa L. seed. Interational Immunopharmacology, 5: 1749-1770.

Sen, A., Khade, S.D., Jana, J.C. and Choudhury, P. 2019. Effect of integrated nutrient management on growth, yield and quality attributes of black cumin (Nigella sativa L.) var. Rajendra Shyama grown under terai region of West Bengal. Journal of Spices and Aromatic Crops, 28: 61-65.

Sheoran, O.P. 2004. Statistical package for agricultural research workers. Hisar: CCS Haryana Agricultural University. http://14.139.232.166/opstat/.

Singh, S., Choudhary, M.R., Garhwal, O.P., Jakhar, M.L. and Yadav, B.L. 2012. Effect of biofertilizers and inorganic sources of Nitrogen and Phosphorus on quality production of kasuri methi (Trigonella corniculata). International Journal of Seed Spices. 2: 38-40.

Sultana, S., Das, B., Rudra, B.C., Das, G. and Alam, M.B. 2018. Effect of date of sowing on productivity of black cumin. International Journal of Current Microbiology and Applied Science, 7: 1796-1800.

Valadabadi, S.A. and Farahani, H.A. 2013. Investigation of biofertilizers influence on quantity and quality characteristics in Nigella sativa L. International Journal of Agricultural Research and Development. 1: 61-64. 